> Tips om medisinsk litteratur, andre bøker, filmer og elektroniske medier

som bør anmeldes, sendes tidsskriftet@legeforeningen.no

\title{
Innblikk i psykoterapi med barn og ungdom
}

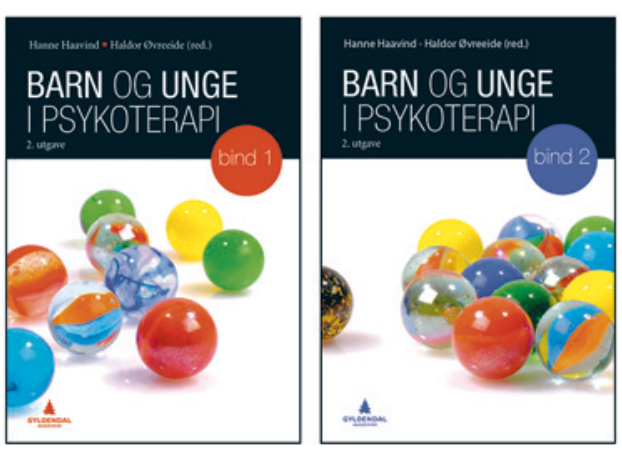

Hanne Haavind, Haldor Øvreeide

Barn og unge i psykoterapi - bind 1 og 2

2 bd. 604 s, tab, ill. Oslo: Gyldendal Akademisk, 2016. Pris NOK 958

ISBN 978-82-05-48755-0

ISBN 978-82-05-48756-7

Målgruppen er behandlere som arbeider med barn og ungdom med følelsesmessige problemer, og målet er å bidra til forståelse for prosesser som fremmer endring.

Bøkene er en antologi med forskjellige forfattere. Redaktørene er Hanne Haavind, professor i psykologi ved Universitetet i Oslo, og Haldor Øvreeide, psykologspesialist som driver Institutt for familie og relasjonsutvikling på Os. De fleste av forfatterne har tilhørighet i fagfellesskapet rundt Institutt for Aktiv Psykoterapi. Alle forfatterne legger vekt på å stå i en evidensbasert tradisjon, og de beskriver sin faglige forankring til begreper som sosialkonstruktisme, fenomenologi, humanisme og eksistensialisme.

Det er angitt at boken er utgitt $i$ to bind av praktisk årsaker, de utgjør til sammen 604 sider. Dette er andre og revidert utgave. Første utgave kom i 2007. Noen kapitler er helt oppdatert, og det er i tillegg fire helt nyskrevne kapitler. Referansene er noen steder oppdatert, mens det hos noen forfattere synes å være gjort små endringer. Begge bøkene starter med samme introduksjonskapittel før de har en kort oppsummering av hovedinnholdet i hvert kapittel i det aktuelle bindet. Kapitlene er ikke organisert etter tema, men etter forbokstavene i forfatternes fornavn. Det kan bli litt forvirrende for leseren, men den korte oppsummeringen $\mathrm{i}$ begynnelsen av hvert bind gjør det lettere å orientere seg. Noen forfattere illustrerer stoffet med bilder eller tabeller, men det er i hovedsak tekstfremstilling av stoffet. Teoridelen av stoffet er gjennomgående belyst med kasuseksempler eller korte vignetter.

Det er vanskelig å gi et samlet bilde av hva så mange forskjellige forfattere vil formidle. De vektlegger alle betydningen av relasjonen og samtalen i forskjellige varianter, utviklingsforståelse og at man alltid må se barnet/ungdommen i den sammenheng de lever. Mange av forfatterne vektlegger det viktige $\mathrm{i}$ å etablere trygghet

og en felles allianse. Alle som har noe erfaring med denne typen arbeid, vet at det krever tid. Det er prisverdig at det utgis en bok med dette søkelyset $i$ en tid hvor det stadig er krav om kortere, tidsavgrensede behandlingsopplegg.

Betydningen av fleksibilitet hos behandlerne vektlegges også. Noen kapitler inneholder en mer generell oversikt over forskjellige sider av behandling av barn og ungdom, mens man i andre fokuserer på mer spesifikke problemstillinger - alt fra det å være skilsmissebarn, streve med atferdsforstyrrelser, til det å ha vært utsatt for alvorlige traumer. Videre er det beskrivelse av spesifikke metoder, for eksempel Marte Meo metode, Parent Management Training og kognitiv behandlingstilnærming. I bind 2 er det også en god oversikt over Statens barnehus - en innføring som gir leseren en god forståelse av hvorfor traumatiserte barn skal kunne forholde seg til bare ett utrednings- og behandlingssted.

Temaet er stort, og det vil naturligvis være mye som ikke vil kunne dekkes. Jeg savner allikevel mer om lek og om utviklingsforståelse sett ut fra en bredere forståelse enn kun følelsesregulering. Kapitlet om nevroaffektiv psykoterapi blir også begrenset av denne avgrensede forståelsen. En teoretiker som Winnicott har bidratt mye til vår forståelse av lek i psykoterapi, slik at flere referanser til hans tenkning ville kunnet utvide her. Fonagy og medarbeideres bidrag om mentalisering som utviklingsforståelse er også et sentralt område som det mangler referanser til.

Boken gir et innblikk i hvordan man jobber psykoterapeutisk med barn og ungdom. For mange vil det være et innblikk som er spennende. For den erfarne terapeut tenker jeg at innholdet i stor grad er kjent, slik at boken kanskje er mest aktuell for studenter som vil få et innblikk i psykoterapi med barn og ungdom.

\section{Rune Johansen}

Spesialist i psykiatri og i barne- og ungdomspsykiatri.

Dr. Johansens spesialistpraksis

Oslo 